\section{Commentary: Winds of change? Not really...not yet!}

\author{
Madhuri V. Rao, MD, ${ }^{a}$ and Rosemary F. Kelly, MD \\ "When I'm sometimes asked when will there be \\ enough [women judges on the US Supreme Court \\ bench] and I say, 'When there are nine,' people are \\ shocked. But there'd been nine men, and nobody's \\ ever raised a question about that."
} —Ruth Bader Ginsburg

The literature is flooded with studies demonstrating unequal representation of women as session leaders in national and international scientific meetings in all fields, including surgery. ${ }^{1-4}$ In the current study, Shemanski and colleagues ${ }^{5}$ extend this well-established fact to cardiothoracic surgery. Their article is not just another study about the same thing. The authors highlight the pervasive and persistent nature of the problem through their descriptive study of the gender of session leaders at 4 cardiothoracic surgery organizations' annual meetings from 2015 to 2019 . They found that while women as session leaders trended positively overall for the 5 years, it was only because of the positive trend in proportion of thoracic female session leaders. There was no significant change for adult cardiac or congenital cardiac surgery, and there was no change in panel composition, with the majority of expert panels remaining men only. These findings reflect that of the regional and national society leadership from 2015 to 2019, as the percentage of women on board of directors and councils also remaining statistically unchanged. This lack of diversity is holding us back.

At this time, we have the opportunity to advance our specialty in far reaching ways. For years, the corporate world has shown us that prioritizing employee diversity results in greater profitability. ${ }^{6}$ Companies committing to $30 \%$ or

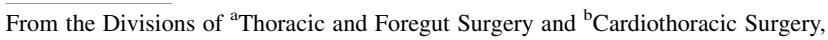
University of Minnesota, Minneapolis, Minn.

Disclosures: The authors reported no conflicts of interest.

The Journal policy requires editors and reviewers to disclose conflicts of interest and to decline handling or reviewing manuscripts for which they may have a conflict of interest. The editors and reviewers of this article have no conflicts of interest.

Received for publication Dec 8, 2020; revisions received Dec 8, 2020; accepted for publication Dec 9, 2020; available ahead of print Dec 31, 2020.

Address for reprints: Rosemary F. Kelly, MD, Cardiothoracic Surgery, 420 Delaware St SE, Mayo Mail Code 207, Minneapolis, MN 55455 (E-mail: kelly071@umn. edu).

J Thorac Cardiovasc Surg 2021;161:746-7

$0022-5223 / \$ 36.00$

Copyright (c) 2020 by The American Association for Thoracic Surgery

https://doi.org/10.1016/j.jtcvs.2020.12.058

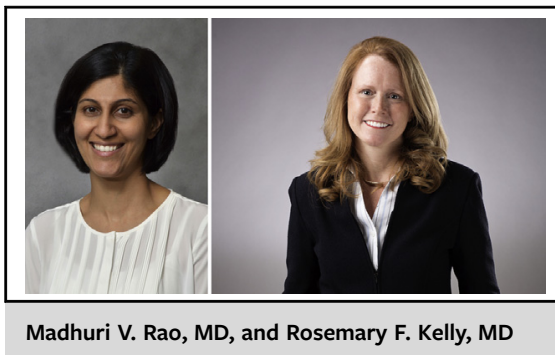

CENTRAL MESSAGE

Cardiothoracic surgery has seen limited measurable change over decades in the equity and diversity of its leadership. Meaningful change requires focused efforts on implementation and accountability.

more women in leadership positions had greater net margins than companies that lacked this degree of female representation. $^{7}$ Similarly, diversity in the physician workforce translates into improved health care outcomes. ${ }^{8,9}$ Acknowledging this reality, medical schools have achieved gender equity and women now compose more than $50 \%$ of classes. Surgical specialties had to adjust residency training as they saw their applicant pool diminish. In thoracic surgery residency, women now comprise $24.3 \%$ of residents through initiatives such as work hour limitations, I-6 programs, and focused national mentoring and scholarships. ${ }^{10} \mathrm{We}$ need to build on this success and create diversity at all levels of leadership roles in our specialty.

Deliberate action toward gender equity in cardiothoracic leadership will positively impact our specialty. The authors appropriately argue that progress will require that leadership aim for goal demographics rather than accept representation that reflects the low percentage of women in cardiothoracic surgery currently. Committees for our annual societal meetings must set clear goals for panel and program planning composition that ensure diversity and inclusion. Quantifying this in terms of an actual number or percentage as opposed to an arbitrary recommendation would facilitate the process. Cardiothoracic surgeons must support these initiatives and hold leaders of our societies accountable to this expectation to improve our specialty. It is time to change the status quo.

"You are what you do, not what you say you do." -Carl Jung 


\section{References}

1. Kibbe MR, Kapadia MR. Underrepresentation of women at academic medical conferences-"manels" must stop. JAMA Netw Open. 2020;3:e2018676.

2. Gerull KM, Kim DJ, Cogsil T, Rhea L, Cipriano C. Are women proportionately represented as speakers at orthopaedic surgery annual meetings? A crosssectional analysis. Clin Orthop Relat Res. 2020;478:2729-40.

3. Wilcox AR, Trooboff SW, Lai CS, Turner PL, Wong SL. Trends in gender representation at the American College of Surgeons Clinical Congress and the Academic Surgical Congress: a mixed picture of progress. J Am Coll Surg. 2019; 229:397-403.

4. Johnson CS, Smith PK, Wang C. Sage on the stage: women's representation at an academic conference. Pers Soc Psychol Bull. 2017;43:493-507.

5. Shemanski KA, Ding L, Kim AW, Blackmon SH, Wightman SC, Atay SM, et al. Gender representation among leadership at national and regional cardiothoracic surgery organizational annual meetings. J Thorac Cardiovasc Surg. 2021;161: 733-44.

6. Quarterly M. Is there a payoff from top-team diversity? 2012. Available at: https://www.mckinsey.com/business-functions/organization/our-insights/is-ther e-a-payoff-from-top-team-diversity. Accessed December 13.

7. Noland M, Moran T. Study: firms with more women in the C-suite are more profitable; Available at: https://hbr.org/2016/02/study-firms-with-more-women-inthe-c-suite-are-more-profitable. Accessed December 13, 2020.

8. Cooper-Patrick L, Gallo JJ, Gonzales JJ, Vu HT, Powe NR, Nelson C, et al. Race, gender, and partnership in the patient-physician relationship. JAMA. 1999;282: 583-9.

9. Wallis CJ, Ravi B, Coburn N, Nam RK, Detsky AS, Satkunasivam R. Comparison of postoperative outcomes among patients treated by male and female surgeons: a population based matched cohort study. BMJ. 2017;359: j4366.

10. Association of American Medical Colleges. Physician Specialty Data Report 2018. Washington, DC: Association of American Medical Colleges; 2018. $1-7$. 